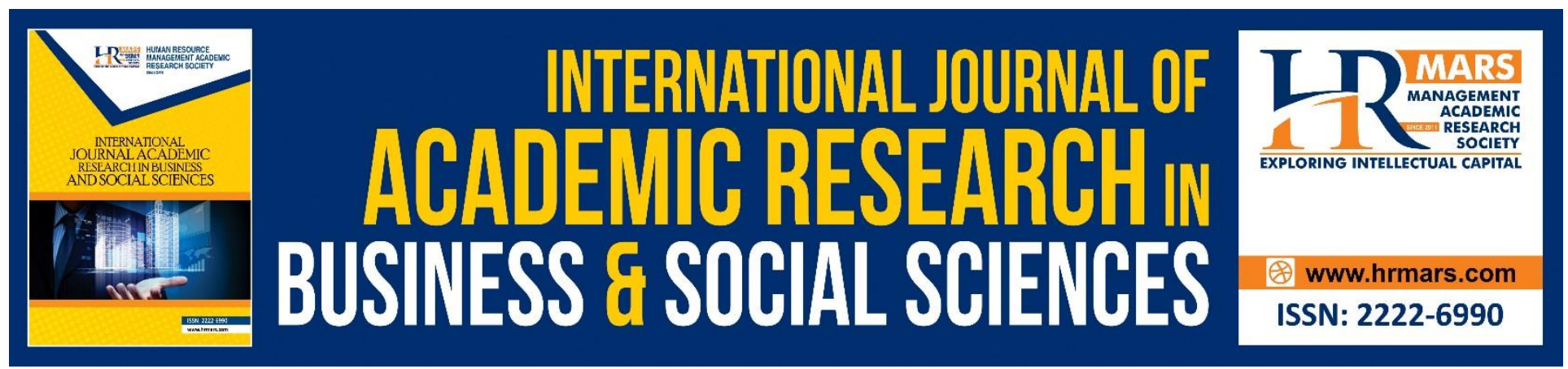

\title{
Foreign Patients' Satisfaction toward Service Quality in Malaysia Private Hospitals
}

\author{
Aslinda Mohd Shahril, Sabaianah Bachok, Anis Amira Amiluddin
}

To Link this Article: http://dx.doi.org/10.6007/IJARBSS/v10-i17/8505

DOI:10.6007/IJARBSS/v10-i17/8505

Received: 10 November 2020, Revised: 13 December 2020, Accepted: 30 December 2020

Published Online: 17 January 2021

In-Text Citation: (Shahril et al., 2021)

To Cite this Article: Shahril, A. M., Bachok, S., \& Amiluddin, A. A. (2021). Foreign Patients' Satisfaction toward Service Quality in Malaysia Private Hospitals. International Journal of Academic Research in Business and Social Sciences, 11(13), 101-115.

Copyright: (C) 2021 The Author(s)

Published by Human Resource Management Academic Research Society (www.hrmars.com)

This article is published under the Creative Commons Attribution (CC BY 4.0) license. Anyone may reproduce, distribute, translate and create derivative works of this article (for both commercial and non-commercial purposes), subject to full attribution to the original publication and authors. The full terms of this license may be seen

at: http://creativecommons.org/licences/by/4.0/legalcode

Special Issue: Beyond 2021 and COVID-19 - New Perspective in the Hospitality \& Tourism Industry, 2021, Pg. $101-115$ http://hrmars.com/index.php/pages/detail/IJARBSS

Full Terms \& Conditions of access and use can be found at http://hrmars.com/index.php/pages/detail/publication-ethics 


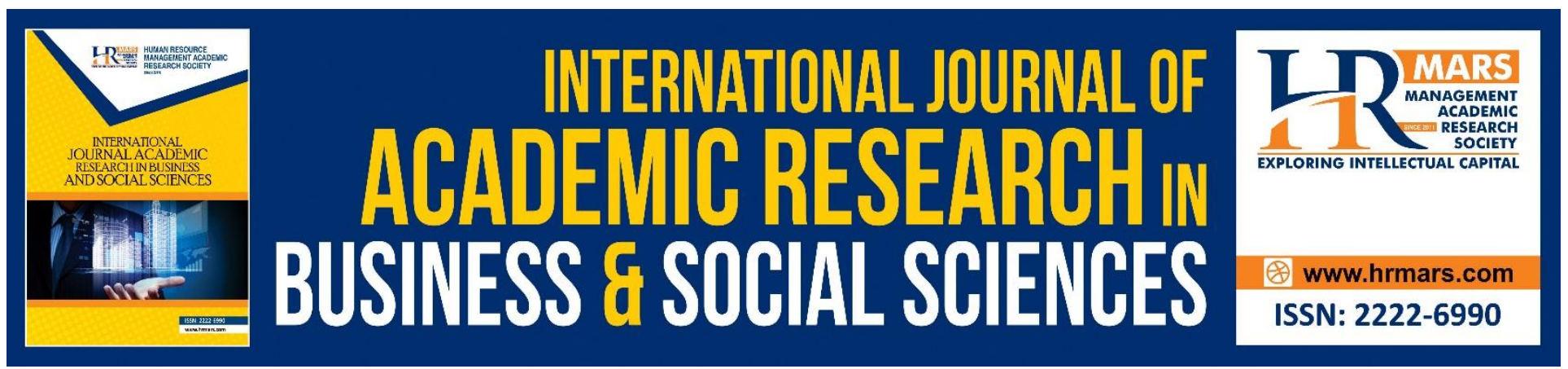

\title{
Foreign Patients' Satisfaction toward Service Quality in Malaysia Private Hospitals
}

\author{
Aslinda Mohd Shahril, Sabaianah Bachok, Anis Amira Amiluddin
}

Faculty of Hotel and Tourism Management, Universiti Teknologi MARA, Puncak Alam Campus, Selangor Branch, 42300, Selangor, Malaysia

\begin{abstract}
Medical tourism is defined as travelling to a different country to receive medical treatment at an affordable cost, and have access to higher-quality healthcare or obtain specialised treatment which they would not receive in their home country. Such medical treatments may involve therapeutic intervention for cancer and cardiac matters through dental and aesthetic surgery. Although medical tourism is quite popular in Malaysia, there are limited studies that examine foreign patients' satisfaction towards services they received from hospitals. Therefore, the aim of this study is to examine customer satisfaction who seek medical treatment in Malaysia specifically in the Klang Valley private hospitals. This study applies a survey design with questionnaires and 100 sets of questionnaires were distributed to foreign patients in 6 private hospitals and the data were analysed using Statistical Package for Social Science (SPSS). The data were analysed and the results indicated that there is a significant relationship between service quality provided by the hospitals and foreign patients' satisfaction. The implications of the study will be useful for practitioners, academicians, and policy makers. Finally, the limitations of the study were addressed and recommendations for future studies are also provided.
\end{abstract}

Keywords: Medical Tourism, Customer Satisfaction, Service Quality, Private Hospitals, Malaysia.

\section{Introduction}

Issues related to healthcare quality are crucial to any health system anywhere in the world. Many researchers have associated the quality of healthcare with patients' expectations and perceptions of quality, stating that "the quality of services is the ability to meet the customers or 'patients' expectation" (Lee, Khong, and Ghista, 2006). Many hospitals discuss about quality and service initiatives, but those initiatives alone may be insufficient for delivering services as expected by consumers. As patients nowadays are opinionated, sophisticated and have experience, they tend to become heavily focused on consumerism. The growth of global healthcare has created medical tourism that offers various medical services to local or international patients. 
Medical tourism is a growing healthcare service industry in developing countries of Asia. It provides an international quality of healthcare services to foreign medical tourist, where new niche markets are emerged. Private medical hospitals, tourism and the hospitality industry are the key supply of stake holders along with the government, which are promoting the development and growth of this industry as an innovative concept to foreign patients and capitalizing on competitive and comparative advantages over tourist's home country. Although Malaysia is facing big challenges on global economic downturn century, medical tourism in Malaysia has become one of the fastest growing segments; positioning the country itself as a leader in specific niches of the industry by offering high quality care and high value of health experiences (“INSIDE MALAYSIA," 2012).

Despite the fact that Malaysia is quite behind in established medical locality such as our neighbouring country, Singapore and Thailand, Malaysia is rapidly becoming a popular terminus for health travellers. However, there are a lack of empirical published papers focusing on service quality in the private hospitals towards the foreign patients' satisfaction. Therefore, this study will explore the relationship and provide some useful findings on the above issue. This study is conducted to measure the level of satisfaction among foreign patients in the private hospital in Selangor, Malaysia towards the service quality provided by the healthcare centre. Consequently, the objectives of this study are to examine the relationship between service quality dimension towards the foreign patient's satisfaction on the private hospital services in Klang Valley. From the findings, this study hopes to contribute to the current body of knowledge pertaining to service quality issues highlighted in private hospitals, particularly in Klang Valley, Malaysia.

\section{Literature Review \\ Medical Tourism in Malaysia}

In Malaysia, medical tourism was introduced immediately after the 1997 Asian financial crisis (UNESCAP, 2007). During this period, private hospitals were experiencing increase in operating costs, along with the reduction of domestic customers. The crisis prompted them to search for alternatives abroad, attracting inbound medical tourists. Statistics have shown that medical tourists arrival in Malaysia have escalated more than tenfold from 30,000 in 1998 to 341,288 in 2007, and have brought in a total revenue of RM253.84 million in 2007 (Cruez, 2008).

Travelling 'patients' are visiting Malaysia for low cost quality medical services and treatment that are either not available or prohibitively very costly within their own country. Malaysia has competitive edge for the exchange rate and therefore, these patients can do multiple surgery here, with the same amount of cost in their own country. Furthermore, the short travel time, the wide range of services, reasonable cost and culture compatibility in terms of religions, language and foods have also motivated travelling patients from neighbouring countries to keep coming to Malaysia. The majority of visitors of this Medical health that keep coming to Malaysia is from the neighbouring countries where they are mostly from Indonesia (69\%), Singapore (12\%), and other travellers are mostly from Japan, Australia, UK and European countries. Patient satisfaction is also ranked among the most important performance measures for healthcare delivery service (Zabada, Sanjay, and Munchus, 2001). Therefore, a survey on 
patients' opinions regarding the provided service is one of the main tools to measure the quality of healthcare services.

\section{Foreign Patients' Satisfaction}

Many studies have been done on international patients' satisfaction but limited studies were done on foreign patients' satisfaction in Malaysia. Focusing on mortality and morbidity rate is just one spectrum of reviewing the competency of a health system but asking the patients about their satisfaction for services provided is becoming a valuable tool for the optimum evaluation of healthcare providers. Patients' satisfaction is now deemed as an important outcome measure for health services; however, "satisfaction" might be translated into various definitions (Whittaker, 2008). Patients may have a complex set of important and relevant beliefs which cannot be embodied in terms of expressions of satisfaction. Zhang, Yang, Li, Huang (2018) conducted a study in hospitals and found that patients appreciated good service quality which enhance their satisfaction and create loyalty. For service providers to meaningfully ascertain the experience and perceptions of patients and the community, research must first be conducted to identify the ways and terms in which those patients perceive and evaluate that service.

\section{Service Quality}

In general, SERVQUAL is considered to be a strong scale for measuring service quality across the service sectors. It is supported by Aditi (2009) who pointed out that SERVQUAL and its adapted versions are suitable for measuring patients' satisfaction. Reliability, responsiveness, assurance, empathy, tangibles, and credibility are the important attributes which are utilised in many sectors dealing with public goods and services. Given that the delivery of healthcare is a public service, there is a high potential to improve the level of patients' satisfaction with the service by tracking these dimensions. Abundance of research that have been conducted only focused on the five common dimensions of SERVQUAL (i.e., tangible, assurance, empathy, responsiveness, reliability).

\section{Responsiveness}

It refers to quality of all the personnel involved in delivering service, namely, doctors, nurses, paramedical, and support staff. The personnel offering service are expected to be responsive, reliable, friendly, sincere, and competent by the customers. Friendly and courteous staff tends to improve patients' perceptions of the hospital. Parasuraman, Zeithaml, and Berry (1985) made use of assurance, empathy and responsiveness dimensions to indicate the quality of personnel. Andaleeb (1998) had three of the five dimensions, "competence of staff", "demeanour", and "communication" related to patient-staff interaction, which reinstated the importance of patient's relationship with hospital employees. Otani and Kurz (2004) stated that "nursing" was more important in improving customer behaviour and behavioural intention than other factors. Rao, Peters, and Bandeen-Roche (2006) found that interpersonal skill of medical personnel was a significant predictor of patient satisfaction. Das and Hammer (2007) found that the personnel quality, particularly doctors' qualification, was worse in government hospitals than private hospitals in India. Baalbaki, Ahmed, Pashtenko, and Makarem (2008) found that nursing was the most influential dimension with respect to patient satisfaction in Lebanon hospitals. 


\section{Assurances}

Firms have to make their employees and customers feel safe and secure, because if either of these is threatened, it exerts a tremendous psychological impact on both. The safety is critical as it relates to the survival concerns, which are basic needs of individuals (Boshoff and Gray, 2004). A service firm failing to make their customers feel safe, loses out on everything. A hospital has to address safety critical issues in order to provide a good service because patients visit hospitals to improve their health status and thereby the quality of their life. Provision of ramps and elevators as well as checking for drugs causing allergic reaction in patients are some of the precautions to be taken by the hospital to avoid any crisis, thus providing a comfortable stay for patients. Further, the safety of customers who have special needs (e.g., use of ramps, elevators) also needs to be considered. Older people (both patients and their attendants) and physically challenged people are in need of special facilities to take care of their needs. This is particularly important in healthcare services, as it deals with the survival of patients. So far, only Duggirala, Rajendran, and Anantharaman (2008) seemed to have used "safety indicators" as a dimension of service quality.

\section{Empathy}

During the whole hospitalization experience and at each "contact point", all employees should demonstrate that they care about the patients, are careful in protecting and enhancing the hospital's reputation, do everything to gain the patients' confidence in the hospital and ensure that patients feel safe during their hospitalization (Boshoff and Gray, 2004). Pakdil and Harwood (2005) studied patient satisfaction on a pre-operative assessment clinic and found that patients were most dissatisfied with waiting time. One of the important issues of administrative processes is the delay at different stages of the patient's hospital stay (Duggirala et al., 2008).

\section{Tangibility}

Infrastructure includes the tangible features of a service delivery (including equipment, appearance of the firm/facility, signage, availability of resources). It is also referred to as man-made physical environment or "services capes". The facilities should not only be visually appealing, but also hygienic, particularly in healthcare service. As services are primarily intangible, customers judge the quality of services based on the tangible aspects of services. Technological capability of a hospital including equipment to test and treat various ailments is a part and parcel of the hospital infrastructure. Parasuraman et al. (1985) in their SERVQUAL model used "tangibles" as a dimension of service quality. Andaleeb (1998), while conceptualizing SERVQUAL, stated that "facility" was a factor of SERVQUAL, in a study on hospitals in the United States. Reidenbach and Smallwood (1990) and Otani and Kurz (2004) used the constructs "physical surroundings" and "pleasantness of surroundings" in their studies respectively, to denote the physical facilities and ambience.

\section{Reliability}

The trustworthiness of hospital measured by the sense of well-being felt in the hospital does influence the confidence the patient has on the hospital. This will in turn play a role in the overall evaluation of service provided. Iyer and Muncy (2004) considered that the level of trust patients had actually varied across the patient categories and segmented the patients based on the level of the trust 
they had on the service provider. Ramsaran (2008) found that reliability as well as fair and equitable treatment were the most important SERVQUAL dimensions influencing patient satisfaction.

\section{Customer Satisfaction}

Customer satisfaction has continuously gained increasing attention in business to measure products or service performance. In the simpler terms, customer satisfaction is regarded as customers' evaluation of their purchases and consumption experience with a product or service to meet the customers' needs (Crooks, Kingsbury, Snyder, and Johnston, 2010). Helms and Mayo (2008) defined customer satisfaction or dissatisfaction as the derivation from the customers' experience with a service encountered and the comparison of that experience to a given standard. In the marketing literature, service satisfaction can be classified as an emotional feeling by the consumers after experiencing a certain service which in turn leads to an individual overall attitude towards purchasing of service (Aditi, 2009). Hence, customer emotional response, feeling, personal experience will determine the satisfaction and dissatisfaction of the service delivered.

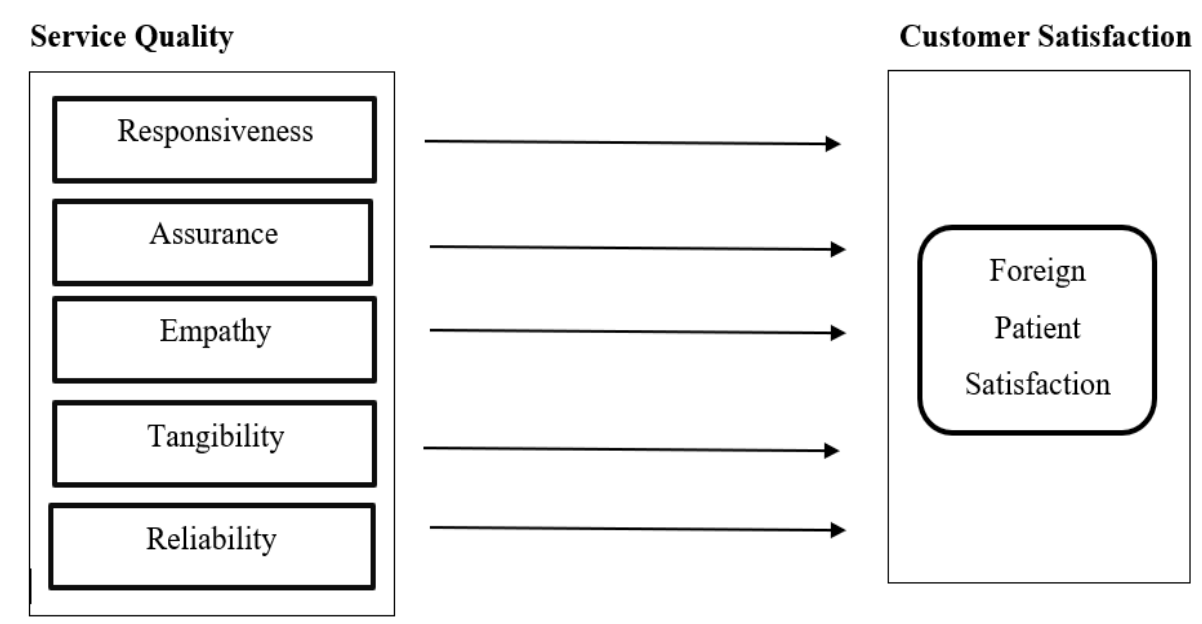

Figure 1: Research Framework

\section{Methodology}

The goal of this research is to study the relationship between customer satisfaction and service quality among foreign patients in the private hospitals in Klang Valley area. The method applied in this study was a form of quantitative data using a structured questionnaire. The questionnaire items were developed based on service quality dimensions used by previous researchers and current study adapted the items based on the suitability of this study. This questionnaire helps the researchers in understanding the factors that affecting the foreign patient satisfaction towards private hospitals services in Klang Valley area. Before the questionnaire were distributed to the real respondents, the researchers performed a pilot test by giving the questionnaire to a few foreign patients. For the purpose of pilot test, 30 foreign patients from one private hospital in Kuala Lumpur were selected. With the researcher assistance, the pilot study was successfully done and the results were analysed. The reliability result showed a satisfactory Cronbach's Alpha value of above 0.60 for each dimension. 
A self-administered questionnaire is chosen due to several factors (i.e., convenience, inexpensive, reduction of biases, and greater anonymity). In this study, the measurement scale of the questionnaire for all the reflective items was based on a five-point Likert type scale. The questionnaire was developed in English as it involved foreigners to answer the survey questions. The target population for this study was the entire foreigners who have come to Malaysia as a medical tourist to receive medical treatment in Malaysia private hospitals. The location for this study consists of six hospitals within and nearest to the Klang Valley area. The researchers wrote an official permission letter to each hospital prior to survey distribution. Only the medical travellers aged 18 years old and above are eligible in answering the survey because they can make decision by themselves and possess the ability to rate the quality of service received. 120 survey questionnaires were equally distributed to six hospitals that include Gleneagles Kuala Lumpur, Prince Court Medical Centre, KPJ Tawakal Health Centre Kuala Lumpur, Pantai Hospital Kuala Lumpur, Subang Jaya Medical Centre and KPJ Ampang Puteri Specialist Hospital. It is impossible for researchers to collect data from all medical travellers, thus non-probability technique is chosen in which the respondents are selected from the population in some non-random manners (Saunders, Lewis, \& Thornhill, 2009). The study made use of a convenience sampling and took a month that start from November to December to complete the survey period and a total of 100 foreign patients answered the questionnaire successfully which represent $83 \%$ response rate.

\section{Results and Analysis \\ Demographic Profiles}

With regards to gender distribution, 33 percent of the respondents were females and 67 percent were males. The majority of the respondents aged between 31 to 41 years old which accounted for 41 percent of the total number of respondents. Majority of the respondents that represent 60 percent of the total number of respondents work as full-time workers in their country and they earn between RM6,000 to RM12,000 per month. They were also asked on the highest educational level and it was found that 67 percent of them were with undergraduate degrees. For this study, 26 respondents were from Indonesia, 22 from Singapore, 19 from Australia, 2 from Japan, 3 from United States, 8 from United Kingdom while others from other countries. 


\section{Descriptive Analysis of the Means and Standard Deviations of the Study Variables}

Table 1: Means and Standard Deviations for Responsiveness

\begin{tabular}{lccccc}
\hline \multicolumn{1}{c}{ Item } & N & Mean & Indicator & $\begin{array}{c}\text { Standard } \\
\text { Deviation }\end{array}$ \\
\hline $\begin{array}{l}\text { The hospital personnel show sincere interest in solving } \\
\text { your problems }\end{array}$ & 100 & 3.03 & Average & .822 \\
$\begin{array}{l}\text { The hospital personnel providing services at appointed } \\
\text { time }\end{array}$ & 100 & 3.98 & High & .791 \\
$\begin{array}{l}\text { The hospital personnel carrying out of the services } \\
\text { right at the first time }\end{array}$ & 100 & 3.63 & High & .971 \\
$\begin{array}{l}\text { The nurses respond to your request immediately in the } \\
\text { case of inconvenience or pain }\end{array}$ & 100 & $\mathbf{4 . 4 8}$ & High & .643 \\
$\begin{array}{l}\text { The prompt performance of medical and non-medical } \\
\text { services by the hospital personnel }\end{array}$ & 100 & $\mathbf{4 . 4 8}$ & High & .643 \\
\hline
\end{tabular}

Table 2: Means and Standard Deviations for Assurances

\begin{tabular}{lccccc}
\hline \multicolumn{1}{c}{ Item } & & & & Indicator & $\begin{array}{c}\text { Standard } \\
\text { Deviatio } \\
\text { n }\end{array}$ \\
\hline $\begin{array}{l}\text { The hospital personnel are polite and friendly } \\
\text { when dealing with you }\end{array}$ & 100 & 3.88 & High & .913 \\
$\begin{array}{l}\text { A skilled doctor is available at all times during } \\
\text { your hospital stay and is aware of your specific } \\
\text { case }\end{array}$ & 100 & 3.79 & High & .891 \\
$\begin{array}{l}\text { The nurses and doctors provide clear explanation } \\
\text { before giving medical care }\end{array}$ & 100 & 4.08 & High & .748 \\
$\begin{array}{l}\text { The nurses and doctors provide a clear } \\
\text { explanation of home medications upon }\end{array}$ & 100 & 3.26 & & Average & \\
discharge & & & & 1.060 \\
\hline
\end{tabular}

Table 3: Means and Standard Deviations for Empathy

\begin{tabular}{lcccc}
\hline \multicolumn{1}{c}{ Item } & N & Mean & Indicator & $\begin{array}{c}\text { Standard } \\
\text { Deviation }\end{array}$ \\
\hline $\begin{array}{l}\text { The hospital personnel can communicate with } \\
\text { patients in English }\end{array}$ & 100 & 4.46 & High & .822 \\
$\begin{array}{l}\text { The hospital personnel in the hospital have a } \\
\text { pleasant tone of voice }\end{array}$ & 100 & 4.41 & High & .740 \\
$\begin{array}{l}\text { The nurses and doctors show empathetic facial } \\
\text { expression }\end{array}$ & 100 & 3.81 & High & 1.032 \\
$\begin{array}{l}\text { The nurses and doctors give your personal } \\
\text { attention (e.g., they address your name every }\end{array}$ & 100 & 4.34 & High & .781 \\
time entering your room) & & & & \\
\hline
\end{tabular}




\begin{tabular}{lcccc}
\hline \multicolumn{1}{c}{ Item } & N & Mean & Indicator & $\begin{array}{c}\text { Standard } \\
\text { Deviation }\end{array}$ \\
\hline $\begin{array}{l}\text { The hospital personnel wear a clean and } \\
\text { professionally dresses }\end{array}$ & 100 & $\mathbf{3 . 6 1}$ & High & .984 \\
$\begin{array}{l}\text { The hospital has state of modern and high } \\
\text { technological equipment }\end{array}$ & 100 & 3.49 & Average & 1.078 \\
$\begin{array}{l}\text { Are your room facilities is clean and } \\
\text { comfortable (e.g., bed and toilet) }\end{array}$ & 100 & 3.38 & Average & .993 \\
$\begin{array}{l}\text { The booklets, pamphlets and statements } \\
\text { contain all necessary information and is in } \\
\text { keeping with the type of service that is } \\
\text { provided }\end{array}$ & 100 & 3.53 & High & .904 \\
\hline
\end{tabular}

Table 5: Means and Standard Deviations for Reliability

\begin{tabular}{|c|c|c|c|c|}
\hline Item & $\mathbf{N}$ & Mean & Indicator & $\begin{array}{c}\text { Standard } \\
\text { Deviatio } \\
n\end{array}$ \\
\hline $\begin{array}{l}\text { Services provided by the employees are } \\
\text { within promised timeframe }\end{array}$ & 100 & 3.63 & High & .971 \\
\hline $\begin{array}{l}\text { Error-free and fast retrieval of } \\
\text { documents by the hospital personnel }\end{array}$ & 100 & 4.48 & High & .643 \\
\hline $\begin{array}{l}\text { Employees are reliable and provide } \\
\text { accurate information to you }\end{array}$ & 100 & 4.48 & High & .643 \\
\hline $\begin{array}{l}\text { Feeling safety and security in } \\
\text { interaction with personnel }\end{array}$ & 100 & 4.30 & High & .785 \\
\hline
\end{tabular}

Table 6: Means and Standard Deviations for Foreign Patient Satisfaction

\begin{tabular}{|c|c|c|c|c|}
\hline Item & $\mathbf{N}$ & Mean & Indicator & $\begin{array}{c}\text { Standard } \\
\text { Deviatio } \\
n\end{array}$ \\
\hline $\begin{array}{l}\text { I am satisfied because service delivers by the } \\
\text { private hospital meet my health requirements }\end{array}$ & 100 & 3.79 & High & .891 \\
\hline $\begin{array}{l}\text { I am satisfied with the quality of service provided } \\
\text { by the private hospital }\end{array}$ & 100 & 4.08 & High & .748 \\
\hline $\begin{array}{l}\text { I am satisfied with the serving process of the } \\
\text { private hospital }\end{array}$ & 100 & 3.26 & Average & 1.060 \\
\hline $\begin{array}{l}\text { In general, I am satisfied with service quality of } \\
\text { the private hospital }\end{array}$ & 100 & 4.26 & High & .676 \\
\hline
\end{tabular}


INTERNATIONAL JOURNAL OF ACADEMIC RESEARCH IN BUSINESS AND SOCIAL SCIENCES

Vol. 11, No. 13, Beyond 2021 and COVID-19 - New Perspective in the Hospitality \& Tourism Industry. 2021, E-ISSN: 2222-6990 @ 2021 HRMARS

\section{Pearson Correlation Analysis}

Table 7: Correlational Analysis for Each of the Variable

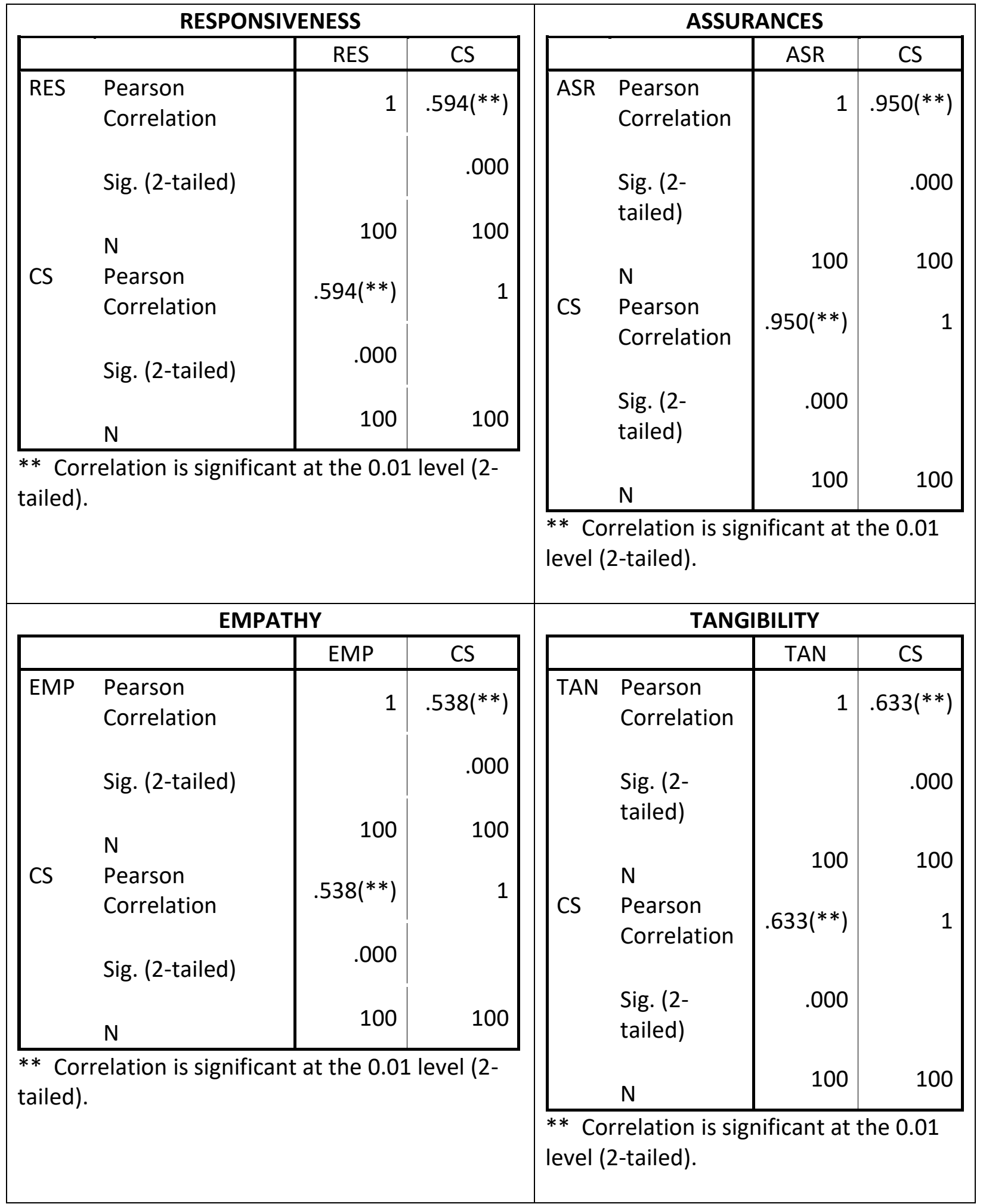


INTERNATIONAL JOURNAL OF ACADEMIC RESEARCH IN BUSINESS AND SOCIAL SCIENCES

Vol. 11, No. 13, Beyond 2021 and COVID-19 - New Perspective in the Hospitality \& Tourism Industry. 2021, E-ISSN: $2222-6990$ @ 2021 HRMARS

\begin{tabular}{|c|c|c|c|}
\hline \multicolumn{4}{|c|}{ RELIABILITY } \\
\hline & & REL & $\mathrm{CS}$ \\
\hline \multirow[t]{3}{*}{ REL } & $\begin{array}{l}\text { Pearson } \\
\text { Correlation }\end{array}$ & 1 & $.569(* *)$ \\
\hline & Sig. (2-tailed) & & .000 \\
\hline & $\mathrm{N}$ & 100 & 100 \\
\hline \multirow[t]{3}{*}{ CS } & $\begin{array}{l}\text { Pearson } \\
\text { Correlation }\end{array}$ & $.569(* *)$ & 1 \\
\hline & Sig. (2-tailed) & .000 & \\
\hline & $\mathrm{N}$ & 100 & 100 \\
\hline
\end{tabular}


Based on the Table 7, the correlational matrix for the five-examined construct which were responsiveness (RES), assurance (ASR), empathy (EMP), tangibility (TAN), reliability (REL), and customer satisfaction (CS). The relationships among all of the constructs were positive and significant at 0.01. For instance, the assurance has shown a positive relationship with customer satisfaction, $r=0.950$. Next, tangibility has a positive relationship with customer satisfaction, $r=0.633$, responsiveness has a positive relationship with customer satisfaction, $r=0.594$, reliability has a positive relationship with customer satisfaction, $r=0.569$, and empathy has a positive relationship with customer satisfaction, $r=0.538$. Based on the positive correlational results, it could be said that there is a significant relationship between foreign patient's satisfaction towards service quality in private hospitals.

\section{Implications of the Study}

Malaysia is one of the major-medical tourism destinations in the world. Thus, the managers of Malaysian hospitals must broaden their perspectives and continuously analyse competitors' marketing activities to compete successfully in this market. Besides, managers of the hospitals must be aware of the importance of those factors that influence their customer satisfaction. It is critical for managers to continuously improve themselves professionally. Findings from this study provide some useful directions for the management and the marketing of the healthcare services.

The results also suggested that customers' overall satisfaction is vital. Healthcare organisations should therefore aim to maintain their existing customers. The results highlighted the importance of providing high-quality services. By concentrating well on service quality, managers can also understand customer satisfaction better. Therefore, such information allows them to make informed decisions to adopt appropriate strategies and policies. It is imperative that managers and decision-makers not only focus on what is important as they must focus on the satisfaction levels of the actual services delivered as well. Service quality is intangible and difficult to evaluate. These findings also indicated the importance for the Malaysian healthcare organisations to continuously boost customer satisfaction to retain current customers and attract new customers. The key is to understand the drivers and to start benchmarking and tracking customer satisfaction.

Organisations will be successful if they can recognise that customer satisfaction is a critical strategic weapon that can increase market share and profits. This research contributes to the knowledge in the current field of interest. It also helps healthcare management in its attempt to understand medical tourism services better. In order to create effective marketing strategies for products and services in the Malaysian medical tourism industry, a better understanding of tourist's medical needs and demands is advised.

\section{Limitations of the Study}

There are several limitations that have been identified and are important to be pointed out for the researchers to learn and acknowledge. The main limitation of this research is to get hospitals permission for survey distribution. Due to this challenge, the study could only collect back a total of 100 sets of questionnaires from the patients. Although there are many hospitals that promoted medical tourism in the chosen area, only a few of the administrators were passionate about granting 
permission to interview their patients. Although the researcher requested the permission by sending an official letter from faculty to distribute surveys to almost 20 private hospitals that was officially registered under the Malaysia Healthcare Travel Council, but only six private hospitals gave their permissions to collect data from their establishment. The administrators may have been hesitant to grant the permission because of the privacy concerns of both the hospitals and patients.

Secondly, the researchers prepared an English version of questionnaire to the respondents and did not prepare questionnaires on other languages. Thus, it has caused some difficulties to some of the respondents who are unable to fully understand certain questions that have been asked due to low English competency. Specifically, Japanese foreign patients mentioned that they have some difficulties in answering few questions. Thus, they would rather follow their intuitions to answer it which can cause bias to the results.

\section{Conclusion}

As a conclusion, the study findings may assist the medical tourism industry and healthcare industry to make service improvement to maximize its business performance. This study might help the tourism and healthcare industry to keep track of the five important dimensions in service quality and continuously monitor their service delivery in ensuring maximum satisfaction among its customers. Medical tourism, although a new phenomenon in its current form, has grown robustly both in terms of the revenue it generates and the geography of its distribution. As the healthcare industry becomes more and more competitive, service quality and customer satisfaction become of paramount importance.

\section{Recommendations for Future Research}

To increase the generalizability of the findings, future researchers can invite more patients to participate in the study to improve the accuracy and the reliability of the result. Additionally, future researchers can expand the sample size by conducting a similar study focusing on other private hospitals in different states in Malaysia. For the current study, the researchers only distributed the questionnaires to private hospitals in Klang Valley which might not be a comprehensive enough to represent the whole population. Thus, to obtain a large sample size, the future researchers can distribute survey questionnaire to all other private hospitals in other states in Malaysia. To avoid bias in the future study, a multi-language questionnaire is highly recommended to invite more respondents to answer the questionnaire.

\section{Corresponding Author}

Aslinda Mohd Shahril. Faculty of Hotel and Tourism Management, Universiti Teknologi MARA, Puncak Alam Campus, Selangor Branch, 42300, Selangor, Malaysia.

E-mail: aslinda@uitm.edu.my

\section{References}

Andaleeb, S. S. (1998). Determinants of customer satisfaction with hospitals: A managerial model. International Journal of Healthcare Quality Assurance, 11, 181-187. 
Aditi, N. (2009). Factors affecting patient satisfaction and healthcare quality. International Journal of Health Care Quality Assurance, 22(4), 366 - 381. http://dx.doi.org/10.1108/09526860910964834.

Baalbaki, I., Ahmed, Z. U., Pashtenko, V. H., \& Makarem, S. (2008). Patient satisfaction with healthcare delivery systems. International Journal of Pharmaceutical and Healthcare Marketing, 2, 4762.

Boshoff, C., \& Gray, B. (2004). The relationship between service quality, customer satisfaction and buying intentions in the private hospital industry. South African Journal of Business Management, 35(4), 27-37.

Cruez, A. F. (2008). Medical tourists coming to Malaysia in thousands. News Strait Times. Retrieved from http://www.malaysiahealthcare.com/04082008.htm.

Crooks, V. A., Kingsbury, P., Snyder, J., \& Johnston, R. (2010). What is known about the patient's experience of medical tourism? A scoping review. BMC Health Services Research, 10.

Das, J., \& Hammer, J. (2007). Money for nothing: The dire straits of medical practice in Delhi, India. Journal of Development Economics, 83(1), 1-36, https://doi.org/10.1016/j.jdeveco.2006.05.004

Duggirala, M., Rajendran, C., \& Anantharaman, R. N. (2008). Patient-perceived dimensions of total quality service in healthcare. Benchmarking: An International Journal, 15(5), 560-583.

Helms, M. M., \& Mayo, D. T. (2008). Assessing poor quality service: Perceptions of customer service representatives. Managing Service Quality, 18(6), 610-622.

Inside Malaysia. (2012). 131. Retrieved from etp.pemandu.gov.my.

Iyer, R., \& Muncy, J. A. (2004). Who Do You Trust? Marketing Health Services, 24(2), 26-30.

Otani, K., \& Kurz, S. (2004). The impact of nursing care and other healthcare attributes on hospitalized patient satisfaction and behavioral intentions. Journal of Healthcare Management, 49(3), 181196.

Parasuraman, A., Zeithaml, V. A., \& Berry, L. L. (1985). A conceptual model of service quality and its implications for future research. Journal of Marketing, 49(4), 41-50.

Lee, P. M., Khong, P. W., \& Ghista, D. N. (2006). Impact of deficient healthcare service quality. The TQM Magazine, 18(6), 563-571. doi:10.1108/09544780610707075

Ramsaran-Fowdar, R. R. (2008). The relative importance of service dimensions in a healthcare setting. International Journal of Health Care Quality Assurance, 21, 104-24.

Rao, K. D., Peters, D. H., \& Bandeen-Roche, K. (2006). Towards patient-centered health services in India: A scale to measure patient perceptions of quality. International Journal for Quality in Healthcare, 18, 414-21.

Reidenbach, R. E., \& Smallwood, S. B. (1990). Exploring perceptions of hospital operations by modified SERVQUAL approach. Journal of Health Care Marketing, 10(4), 47-55.

Saunders (2003). Research Method or Business Students, 3rd edition. New York: Prentice Hall.

UNESCAP. (2007). Patients without borders: An overview of the medical travel industry in Asia, its challenges and opportunities. Paper presented at the UNESCAP EGM, Bangkok, Thailand

Whittaker, A. (2008). Pleasure and pain: Medical travel in Asia. Global Public Health, 3(3), $271-290$. https://doi.org/10.1080/17441690701463936 
INTERNATIONAL JOURNAL OF ACADEMIC RESEARCH IN BUSINESS AND SOCIAL SCIENCES

Vol. 10, No. 17, Beyond 2020 and COVID-19 - New Perspective in the Hospitality \& Tourism Industry. 2020, E-ISSN: $2222-6990$ @ 2020 HRMARS

Zabada, C., Singh, S., \& Munchus, G. (2001). The role of information technology in enhancing patient satisfaction. British Journal of Clinical Governance, 6(1), 9-16. https://doi.org/10.1108/14664100110384948

Zhang, Y., Yang, M. M., Li, S. J., \& Huang, Y. Y. (2018). Hospital service quality and patient loyalty: the mediation effect of empathy. Journal of Business and Industrial Marketing, 33 (8), 11761186. 